\title{
FEMINISM AND CRITICAL EDUCATIONAL GERONTOLOGY: AN AGENDA FOR GOOD PRACTICE
}

\author{
MARVIN FORMOSA
}

\begin{abstract}
The aim of this research piece is to focus on the 'empowering' potential inherent in that interface between feminist gerontology and critical educational gerontology. Following a feminist criticism of critical educational gerontology as yet another patriarchal discourse where women are silenced and made passive through their invisibility, I attempt to construct a critical agenda for feminist educational gerontology. Field research was carried out at the University of the Third Age (U3A) in Valletta (Malta), due to the fact that the U3As represent one of the most successful and important educational program specifically developed for older persons. Data analyses reveal the necessity of introducing five principles for the founding a truly feminist educational experience in later life, namely: acknowledging older women as an oppressed population due to the 'double standard of aging'; a focus on women's lifelong cumulative disadvantages; emphasizing a 'politics of difference'; embracing a feminist praxis in both older adult education and research activities; and finally, embodying a drive towards the empowerment of older women in a distinct but collective effort.
\end{abstract}

\section{Rationale}

It is welcome to note that over the past decade, social gerontologists have begun to apply feminist perspectives better to comprehend the complexities inherent in the lives of older women. Despite the diverse interests, many supported Sontag's (1975) 'double standard of aging' for older women due to the combination of ageism and sexism, as well as to that the male-centered bias present in gerontological theorizing and policy-decisions. It is also welcome that some publications (e.g., Laws, 1995; Browne, 1998) provided theoretical and practical possibilities towards the elimination of existing patriarchal-ageist subjugations. Examining such publications, one notes that educational practice featured as a consistent recommendation for feminist transformation. Yet,

Ageing International, Fall 2005, Vol. 30, No. 4, pp. 396-411. 
it is lamentable that whilst on one hand educational gerontology is devoid of a feminist discourse (Ray, 1999), on the other feminist adult education is oblivious to older women (Gibson and Allen, 1993). In educational gerontology, the distinct experience of older women is even surprisingly sidestepped in 'critical educational gerontology' [CEG], as that branch of older education exclusively concerned towards the empowerment and emancipation of older adults. This has created a situation where the inherent potential of educational practice to act as a catalyst towards the empowerment of older women is still an unknown and underutilized terrain. It was precisely to focus on the 'empowering' potential inherent in that interface between feminist gerontology and CEG this study on older adult education was developed. In order to situate the research in an empirical setting action research was conducted at the University of the Third Age in Valletta, Malta.

\section{The Personal Is Political}

Reflecting feminists' concern with the tenet that 'the personal is political', a brief autobiographical note is relevant. With respect to the present publication, it is useful to clarify that the author wears three hats. First, I consider myself to be a critical educator. My early years were characterized by a working-class familial environment. However, I succeeded in graduating in psychology, sociology and education, and got my first teaching job in a remedial school where I experienced Bourdieu's (1995) claim that schools constitute the pre-eminent institutional machinery for the certification of social hierarchies. Dispirited by the authenticity of Bourdieu's claim, but fuelled by an optimistic personality, I embraced Paulo Freire's (1972a) critical educational standpoint as a potential strategy to transform existing oppressive realities. My second hat is of a critical gerontologist. This resulted from the awareness that both mainstream gerontology and old age social policies generate a new form of domination over older persons exercised in an increasingly skilful manner by the elite. This was experienced in a personal manner when my grandmother experienced extensive poverty in her later life-despite experiencing two World Wars and contributing to society in various positive ways. My final hat is that of a heterosexual male. This hat is central with respect to the aims and objectives of this publication considering that some social scientists may endorse Heath's (1987: 1) claim that 'men's relation to feminism is an impossible one'. Yet, this argument is clearly essentialist since it equates unjustly manhood with oppression and inequality, ignoring documented research (e.g., Kimmel, 1995) that highlighted the many male feminist activists. Here, I concord fully with Hopkins (1998: 50) who stated that what is 'important about being a feminist is not that one perceives as a woman, but [to] perceive and understand as a feminist'. 


\section{Critical Feminist Gerontology}

Critical feminist gerontology resulted as that interface between feminism and critical gerontology (Ray, 1999). Whilst it is true that definitions of the term 'feminism' are criticized for depicting a limited shared content, one can locate three common foundations: (i) a political commitment to improve the conditions of women, (ii) a critical perspective of male-dominant forms of knowledge, and finally, (iii) a praxeological dimension concerned with the development of liberating forms of practice (Weiner, 1994). One, would be however misled to assume that such endeavours are employed in an onedimensional assault on patriarchy. As stated aptly by hooks (1981: 194) feminism is not simply a struggle to end male chauvinism or a movement to ensure that women will have equal rights with men but a 'commitment to eradicating the ideology of domination that permeates Western culture on various levels' as well as a dedication to 'reorganizing [society] so that the self development of people can take precedence over imperialism, economic expansion, and material desire'. Critical gerontology, on the other hand, refers to an analysis of later life that is concerned with 'normative questions, material interests, the functioning of gerontology itself and other factors that are regarded by the mainstream as only of 'contextual' importance' (Baars, 1991: 221). Critical gerontology strives to go

...beyond everyday appearances and the unreflective acceptance of established positions...to analyse how and why gender, race, class and other inequalities are so often ignored and places questions about meaning and fulfillment in later life back on the agenda in the search for solidarity between groups (Estes et al., 2004: 3).

Although there is no specific school of critical gerontology (Achenbaum, 1997), it is however possible to discern three major strands: (i) an epistemological critique of obsessive objective measurements of gerontological variables, (ii) a humanistic perspective attempting to understand the meaning of the aging experience through literature, narratives, diaries, etc, and finally, (iii) an 'emancipatory enterprise' that strives toward a liberation from the system of domination and from a depreciation of the meaning of old age (Minkler, 1996).

Feminist gerontology is concerned with the utilization of theories/methods that depict female lives more accurately in the hope of nurturing a social consciousness about the higher levels of inequalities experienced by older women (Brown, 1999; Garner, 1999; Casalanti, 2004). Thus, the concern of feminist gerontologists is 'to empower older women through assisting them in developing new roles, in identifying their abilities and strengths, and in utilizing their knowledge' (Garner, 1999: 7). Critical gerontology was excellently interwoven with feminist gerontology in Ray's Researching to Transgress, which argued that critical feminist gerontology $(\mathrm{CFG})$ : 
[first] challenges the scientific paradigm by being personally 'involved' and critical (as opposed to distanced and objective), as well as overtly political (in the sense of advancing an agenda meant to empower both the researcher and re-searched), and [secondly] pursues alternative ways to report scholarly findings which are equally 'involved' and critical (Ray, 1999: 173).

In Ray's view, CFG is not an attempt to criticize other existing stands of feminist gerontology or as an exertion to formulate a more adequate feminist paradigm in gerontology: it strives for disciplinary border crossings, paradigm shifting, and 'genre-bending' with the purpose of empowerment by standing on the shoulders of the preceding feminists. Ray lists four major principles for CFG. First, researchers must pursue an involvement with both gerontological discourse and individuals' concerns-aiming to comprehend the subject's experiences whilst sharing their own feelings and experiences. This results in a disconnection between formal and personal relations that may give birth to personal relationships that may mature over time. Secondly, research must be embedded in a critical dimension. CFG rejects that the goal of research is to discover and document laws of human behavior as this reinforces power relations and bureaucratic forms of control. CFG does not attempt to solve problems as defined by the social elite, but aims to raise and identify hidden problems that the elite adapt to but do not solve. Third, researchers and research generated must be directed by a political commitment. Research thus becomes an endeavor to empower, an attempt to confront the injustice of a particular society, unembarrassed by the label 'political' and unafraid to take on an emancipatory consciousness-even if this means to 'rock the boat'. Finally, researchers must pursue alternative ways to report scholarly findings that are equally involved and critical. Research results must not be presented in a detached and neutral way where the author is hidden, but be embedded in theatrical, expressive, or dramatic styles that can take the form of a work of fiction, a movie or play.

Now that an analytical overview of (critical) feminist gerontology has been presented, the next section focuses on critical educational gerontology as that 'provision of education for older adults should relate to their gaining power over their lives' (Glendenning and Battersby, 1990: 222).

\section{Critical Educational Gerontology}

Critical educational gerontology emerged first from the radical concern to overcome the oppressions which locked older adults into ignorance, poverty and powerlessness, and secondly, as a reaction to the uncritical acceptance of the language and the underlying ideological approach employed in older adult education. As expected from such rationales, critical educational gerontology drew heavily on the dialectical ideals of Paulo Freire (1972a) on transforma-

tive educational practice which recognises the political nature of all education 
interventions, and whose pedagogical work incorporates what Giroux (1985: xiv) termed as the languages of 'critique' and 'possibility'. Freire's (1972a) shared Marx's (1964) and Gramsci's (1971) concern as to how ideology serves to sustain an oppressive social formation and departs from the view that the ruling class governs the non-powerful classes through direct coercion. In this respect, he maintained that the dominating classes employ educational practice, in the form of banking education, to instil a submissive and compliant consciousness amongst the dominated (Mayo, 1999). Banking education is referred to as an

an act of depositing, in which the students are the depositories and the teacher the depositor...the teacher issues communiqués and makes deposits which the pupils patiently receive, memorize and repeat ... the educator's role is to regulate the way the world 'enters into' the students (Freire, 1972a: 45-46, 49).

Against such a social background, Freire (1972b) turned to Marx and Engels' (1963) early humanist phenomenological writings, to devise a role for education that leads to 'cultural freedom' from the state of oppression. Education would thus invert its domesticating role to one of praxis at the service of permanent human liberation-a counter-hegemonic activity that would liberate human beings from their state of 'dehumanization'. Freire's (1985: 80) most revolutionary and subversive tenet in his pedagogy is the explicit notion of the political nature of education: 'education is a political act, whether at the university, high school, primary school, or adult literacy classroom'. In contrast to banking education, liberatory education involves a constant unveiling of reality and strives for the emergence of consciousness and critical intervention in reality (Freire, 1972b). Through liberatory education, the subject is able to achieve critical consciousness - a state of mind where the world is recognized 'not as a given world, but as a world dynamically in the making' (Freire, 1985: 106).

The first incursion of transformative education in educational gerontology is found in Paula Allman's (1984) rationale where she claimed that the enhancing of the quality of life of older people will not be achieved by just any learning experience but only education that enabled learners to be in control of their thinking. More specifically, Allman (1984: 87) argued that older adult education would lead to the emancipation of older persons only if the selfhelp concept of elder learning leaves older people in control of their own thinking rather than being subjected to the thinking of others, and concluding by insisting that older adult educational practice must experience a collective process of dialogue and reflection where 'learners will be in control of their thinking rather than in the control of others'.

These thoughts were later elaborated in the work of Glendenning and Battersby (1990: 220-1) who argued that most older adult educational programs is based upon erroneous taken-for-granted perceptions, which they re- 
ferred to as 'conventional wisdom'. These included 'the tendency to consider elderly people as a relatively homogenous group', the use of the psychological 'deficit' model of older adults' learning abilities, assuming that any type of education emancipates and improves the quality of life of older persons, deliberating about the aims and purposes of education in later life in a shallow manner, disregarding that older adult education is largely driven by middleclass notions of what constitutes education, overlooking the fact that older persons are marginalized to different degrees from society, and finally, assuming that older adult education is exercised in the interests of older people.

Following a sound challenge of such conventional wisdom, Glendenning and Battersby's (1990: 226-8) put forward four major principles for critical educational gerontology (later elaborated in a second co-authored article [Battersby and Glendenning, 1992: 116-120]). These included:

1. a 'shift away from a functionalist approach'....'[A]n exploration of this relationship between capitalism and ageing should occupy a more central position in examining the concept of education in later life'...,

2. going beyond 'educational gerontology' to what we will call 'critical educational gerontology'.... '[A] critique of the dominant liberal tradition involving a negation that education for older persons is essentially a neutral uncontested enterprise',

3. including 'such concepts as emancipation, empowerment, transformation, social and hegemonical control and what Freire calls 'conscientization', and finally,

4. developing 'the notion of praxis' to establish a 'critical gerogogy.... [T] his can lead older people to greater control over their own knowledge and thoughts, or to use Freire's words, promote conscientization'.

Interestingly, Battersby (1987: 7) also proposed and elaborated the concept of 'gerogogy' as 'a liberating and transforming notion which endorses principles of collectively and dialogue central to learning and teaching'. In a distinct Freirean standpoint, Battersby asserted that gerogogy assumes the status, not of an imposed set of prescriptive guidelines and strategies, but as a concept that conceptualizes teaching and learning as a collective and negotiated enterprise amongst older adults (Formosa, 2002).

The remainder of this article aims to present the data elicited from research at the local University of the Third Age as well as their critical-feminist interpretation.

\section{Fieldwork and data analysis}

Malta is a relative latecomer in establishing its University of the Third Age (U3A) as it was only launched in January 1993 and thus after some 20 years of European experience. The U3A was founded as part of the Institute of 
Gerontology within the University of Malta, and is therefore more in accordance with the French U3A model than the British one. The drive behind the founding of the U3A arose neither from responses to community needs nor from requests by older persons themselves. The first U3A program, which was not launched as a pilot project but as a full-scale activity, resulting from the aspirations of academics and government officials working in the field of aging. In the period January-April 2004 I was scheduled to coordinate a series of discussions on Preventing and Combating Elder Abuse, which I conducted from the standpoint of critical educational gerontology [CEG]. I moderated eight sessions-titled Introducing Elder Abuse, Abuse and Neglect in Institutional Settings, Self-Neglect, Understanding Self-Neglect by Older Adults, Gender Issues in Elder Abuse, Understanding Elder Abuse Risk Factors, Programs and Services, and Concluding Comments - that took place once a week from 09.00 to (circa) 10.30. The study group was composed of 25 members of whom 20 were women. Most ages ranged in the 65-75 age bracket although the highest age was 82 . The plan was to conduct a feedback discussion following the end of each session. I invited all the women to attend. The first time I counted fifteen but eventually only nine continued to participate. Some information on this 'faithful core' is presented in the table below.

Prima facia, it was clear that the CEG standpoint was successful in engendering a normative and ethical engagement amongst older learners. My practice of critical gerogogy succeeded in making them more aware of the hegemonic nature of 'normal' learning in older adult education. The older learners also ceased assuming that all programs are examples of good practice or that any education emancipates irrespective of content and pedagogic style. Alison,

\begin{tabular}{|l|l|l|l|l|l|}
\hline Pseudonym & Age & $\begin{array}{l}\text { Marital } \\
\text { status }\end{array}$ & $\begin{array}{l}\text { Educational } \\
\text { attainment }\end{array}$ & $\begin{array}{l}\text { Past } \\
\text { occupation }\end{array}$ & $\begin{array}{l}\text { Husband's } \\
\text { occupation }\end{array}$ \\
\hline Vera & 75 & Single & Secondary & Secretary & - \\
\hline Francesca & 79 & Widow & Secondary & Teacher & Teacher \\
\hline Ingrid & 68 & Single & Secondary & Personal Assistant & - \\
\hline Carmen & 77 & Married & Tertiary & - & Civil Service \\
\hline Alison & 83 & Married & Primary & - & Lieutenant \\
\hline Giorgia & 65 & Widow & Secondary & - & $\begin{array}{l}\text { Clerk } \\
\text { Supervisor }\end{array}$ \\
\hline Evelyn & 69 & Widow & Secondary & - & Draughtsman \\
\hline Mary & 64 & Single & Secondary & Teacher & - \\
\hline Angela & 72 & Married & Secondary & - & $\begin{array}{l}\text { Factory } \\
\text { Supervisor }\end{array}$ \\
\hline
\end{tabular}


for instance, was overjoyed at the possibility of taking part in such a 'studentled' and 'bottom-up' educational classes:

Sharing my ideas and taking part in the development of the curriculum was very beneficial. I found that I count. In previous sessions we used to be presented with various objectives which we had to achieve whether we liked them or not, whether we perceived them as beneficial or not. The great thing about this course was that I had a role in the construction of the agenda.... I feel very elated not because I have learnt but because I have leant what I wanted to learn (Alison).

I always felt uncomfortable in [U3A] classes. Although I believe that learning is the spice of life the lecturers [sic] always treated like kids. We are adults! This course was different. I cannot say that I approve of your strategies in coordinating the sessions but I have to admit that I never felt as educationally fulfilled when you challenged us to think for ourselves rather than expect others to think for us (Mary).

However, this does not mean that the sessions did not suffer from any lacunae. From a feminist perspective, I still perceived them as yet another example of a patriarchal discourse where women are silenced and made passive through their invisibility. Indeed, despite my criticism of mainstream educational gerontology for ignoring the diverse degree of marginalization and heterogeneity in later life, sparse attention was given neither to gender as one of the major variables that augment marginalization in old age and nor to the distinct theoretical/empirical advances in both feminist gerontology and feminist adult education. In fact, I compartmentalized the notion of gender in one particular session rather than as an intervening throughout all areas of interest.

In the concluding session Ingrid rightly complained how my approach made her feel like an 'other':

It is good to know that you are giving attention to the plight of older women. And I did enjoy your emphasis on gender in on of the lectures. However, I feel that we should not seek to dedicate intensive sessions on gender but focus on such a fact of life lightly but continually during all sessions. In this way, we will not be treated as exceptions. This is what I felt, an exception because I am a women.

Another problem that I faced during the sessions was that although no could doubt my feminist credentials, I still thought and acted within a 'maleist' spectrum. Although I did my best to empathize with the subjects' concerns and did my best to come up with examples that concern women, my chances of success would have been better if I was a woman. This is something that troubled me from day one and I was relived when, despite a certain level of hesitation and wariness, Vera brought this issue up :

I am sorry to have this particular comment. I do not want to be insolent or disrespectful but I think that it may be impossible for a 'man' to empathize as much as a 'woman' 
with our concerns and ideas. Like I said, I do not want to be discourteous but how can you understand for example such things as our fear of mastectomy, sexual harassment, and rape? Perhaps it would have been best if sessions also had a female moderator too.

CEG's patriarchal stance is especially evident when one looks at Glendenning and Battersby's (1990) 'conventional wisdom'. Indeed, in positing dialogue at the center of critical gerogogy, one also needs to reflect that in learning groups, men often dominate the discussion, so that women can assert their opinions and participate in a more limited manner. What about the takenfor-granted assumption that programs and content were designed to meet the needs of all older persons, when most emerged as a reflection of masculinist suppositions regarding later life that engender a masculine orientation towards the production of knowledge? What about the commonly held perception that programs which attract an extensive majority of older women are of little value? For instance, another conventional assumption is that older persons enjoy ample leisure time. Yet, for many older women this is simply not the case. I admired many women who added older adult education to their heavy load of household chores and grand-parenting responsibilities. In this respect, CEG is found in default for overlooking that older women face a worse aging experience than men (see Coyle, 1997) due to the 'double jeopardy of old age' as well as due to lifelong cumulative disadvantages.

Another problem, of course, if the assumption of widespread middle classness amongst older generations. As Angela claimed,

we have to be careful when we say that reading newspapers, internet browsing and leaflets can do wonders with the emancipation of older women. In my locality I know of may older women who barely know how to use the phone. They are illiterate and have very low levels of social support. I guess that these individuals will need more direct help to ameliorate their social position.

Another lacuna consists of the absence of the authors' own intellectual biographies. As readers, we have no sense of their own histories and positions in relation to research. We also get the unfortunate impression that there is considerable 'distance' between the authors and older learner, and at no point are the voices of educators and learners present. In fact, I approached the women as personas to be liberated when this might not be case. As Withnall (2000) argued, can it be that CEG's focus to unmask distortions present in mainstream educational gerontology contains the risk of becoming another oppressive discourse?

According to Francesca, the answer is in the affirmative:

As you know I have not spoken much. The reason was that although I have enjoyed the sessions I cannot say that I feel oppressed or feel bad in some way or another. I have a good relationship with my husband and although his pension is average I feel that we can do a lot of things if we are careful. In fact, I am not a feminist and think that 
men and women have different role in life. It is true that many men abuse their wives but the opposite is also true.

A final problematic concern is that CEG fails to theorize and highlight the possible paradoxical moments in later life. In my emphasis on the centrality of 'capitalism' in making sense of and the transformation of existing oppressions in later life and its neglect of the fact that the production of knowledge can take place at the private and personal levels of individuals, I found my stance to be rather 'political economical' than really 'critical':

[I]t is very difficult for me to deal with abuse and oppression emerging from capitalist formations. I have never worked and find it difficult to empathize with a discussion concerning the state, employers and employees (Francesca).

Following such comments there is no doubt that the existing local, partial, and multiple oppressive relationships in later life require a more extensive critique than that provided by political economical standpoints. The mechanisms of power in current western societies have a capillary format that permeates in all directions and which, in particular, may be seen in the constitution of subjects (Foucault, 1980). If outlined and addressed in depth, each 'capillary' will surely assist the CEG in reaching higher liberating levels. My particular project has surely a more limited focus, and concentrates solely on the feminist spatial location. Yet, I treat such as an important step in making sense, and consequently transforming, the multiple, albeit totalizing, interlocking sites of oppressions in later life.

\section{An Agenda for Good Practice}

Following my field research the following principles are a direct attempt to situate a critical educational in a feminist gerontological perspective in hope that older adult education becomes more an actual example of "transformative education' for older women rather yet another euphemism for glorified occupation therapy. I believe that

A feminist educational gerontology is directed by a rational that acknowledges older women as an oppressed population due to the 'double standard of aging'. A central issue in the setting up and planning of feminist educational gerontology is the awareness of the negative effects that ageism and sexism have for older women. This 'double standard of aging' manifests itself in various aspects. For instance, while men are 'allowed' to age naturally without social penalties, the aging female body arouses distaste (Arber and Ginn, 1991). The discrepancy between the societal ideal of physical attractiveness in women and their actual appearance also widens with age, whereas signs of aging in men are not considered so important. Moreover, older women are more commonly ridiculed and referred to by derogatory colloquialisms in jokes, fiction, 
poems, media industry, and film/theatrical productions (Palmore, 1997). They are also less likely to earn a full pension due to breaks in their employment patterns during maternity and family care or to be covered by private pensions when compared to older men-positing a higher incidence of poverty amongst older women than men. Since most older women spend their final stage of life as widows or as single persons, they find it very difficult to find available care-givers, forcing many to become dependent and live in institutions. Finally, one must acknowledge that older women experience more failing health and disabilities, a more limited school education, as well as increasing victimization (see Coyle, 1997).

A feminist educational gerontology acknowledges that the oppressive position of older women is also the result of lifelong cumulative disadvantages. Inequalities between the sexes in old age are not particular to that life stage but are continuous with other gender-based disparities earlier throughout the life course found especially in familial and occupational relations. A radicalfeminist perspective of the former has compared the situation of wives to that of a serf whereby the husband provides money for food, clothing, and protection in return for playing 'their traditional role as takers of shit' by 'absorbing their husbands' legitimate anger and frustration' generated at the workplace (Ansley, quoted in Bernard, 1976: 233). Moreover, the responsibility of housework and care for the children, sick, and older persons is still a female responsibility, wives get fewer of the material benefits of family life than their husbands (Delphy and Leonard, 1992). Focusing on the occupational realm, it is well documented that the majority of women are employed in low-status, lowpaid, sex-segregated work, which offers little opportunity to progress, prosper, or lucrative pensions (Arber and Ginn, 1991). Another area of concern regards educational opportunities of older women when younger. As Browne (1998: 158) rightly argued, older women who hold no educational qualifications because 'education was not important for a girl' cannot be blamed for not having a 'well-paid profession that cushions her retirement years'. Hence, a critical feminist educational gerontology seeks to gear its transforming activities even to past experiences of older women.

A feminist educational gerontology rejects that there is a universalized singular identity among women and emphasizes a 'politics of difference'. Older women's subjugated positions are not solely the result of one's biographical experience but are directly influenced by social, cultural, and political-historical structures-which result in varied social positions. In fact, one locates many groups of women, each of whom encounter different life circumstances: women in single-parent families or in two-parent families; women in lesbian relationships or in heterosexual relationships; black and white women; lowerclass and middle-class women; and so on. Chronological age, even if small, is also crucial since one's location in political history may given younger/older women better or worse life chances. At the same time, women-to-women oppressive relations must be also acknowledged. Such a complex web of posi- 
tions and relationships cannot be adequately addressed through a universal concept of women, known as 'white feminism', since such a category is not marked by other negative distinctions. On the contrary a feminist educational gerontology must be embedded in a 'politics of difference' that fundamentally acknowledges diverse structured inequalities and oppressions. This necessitates a theoretical and practical orientation that is sensitive to paradoxical forces that make space for the many anomalies found in the experiences of older women, and that is therefore perceptive to the local and overlapping aging experiences found amongst diverse cohorts of such a cohort.

A feminist educational gerontology abandons traditional strategies of learning and teaching and embrace a feminist praxis in both older adult education and research activities. A feminist praxis includes a firm commitment to transforming the world through educational activity so that the plight of older women is improved; a rejection of the theory/research divide, so that manual and intellectual activities are symbolically related towards the generation of feminist emancipation; and finally, a integration of the methodological/ epistemological split so that learners are expected to live out the engendered feminist gerontological knowledge in both private and public lives (Weiner, 1994). Consequently, I advocate Weiler's (1991) call to situate a feminist gerogogy in a Freirean standpoint that both complements and augments the latter. In this respect a feminist gerogogy is to be based on the following principles: (i) the educational activity must derive from the older women's experience as well as being continually subject to revision as a result of impending new encounters; (ii) feminist teachers should not take the role of facilitators but must take sides with and are committed to the sufferings of older women; (iii) acknowledging the various modes of domination where everybody is somebody's 'other' by positing the educational activity on 'affinity groups' where learners are 'unified' through 'their activity of mutual critique, support and participation, as each group worked through, as much as possible ways in which the others supported or undercut its own understandings and objectives' (Ellsworth, 1994: 319); (iv) manipulating the institutionally imposed authority of the teacher in a positive sense where 'the authority of the feminist teacher as intellectual finds expression in the goal of making students themselves theorists of their on lives by interrogating and analyzing their own experience' (Weiler, 1991: 462); and finally, (v) enabling the educational activity to take the role of a 'progressive' movement whereby both students and teachers engage actively in counter-hegemonic activities.

Finally, a feminist educational gerontology is ultimately a drive towards the empowerment of older women in a distinct but collective effort. Despite that feminist educational gerontology aims for individual older women to become critically aware of their situation, its transformative vision is a collective one as there are no private solutions for women's issues. Albeit transformative change must commence from a personal feminist consciousness, individual conversions must be eventually translated in a collective effort to bring forth 
structural and political changes. Despite the various modes of oppression present in contemporary society, it is dangerous to focus on questions of identity and individualism, selfhood and experience. Whilst acknowledging the benefits of postmodern feminist gerontology, embracing a total postmodern perspective runs the risk of becoming utilized agenda in favor of relativism and pluralism, which may collapse into individualistic reductionism, dissolving the possibility of collective action, and suppression of political will. Feminist educational gerontology therefore adopts a critical stand in its engagement in transformative education where possibilities for action are undertaken as a 'collective enterprise where different people do piece-work on different aspects of the problem' and where 'each contribution is related to the larger system of ideas' rather than a 'private theory to bear one's name' (Sherwin, 1988: 23).

\section{Conclusion}

This research piece attempted to accentuate the neglect of both educational gerontology and adult education with older women as an oppressed population. It emerged as a reaction to the failure for the establishment of the feminist paradigm shift that feminist scholars predicted in the early seventies. Moreover, this attempt must not be interpreted as an attempt to create a new kind of instrumental knowledge on either feminist gerontology or educational gerontology, but only an attempt to come at a better understanding of that interface between the two fields. Nor is it devoid of any limitations. First of all, it could be well be that my three hats do not fit one head since this runs the risk of not empathizing fully with the structural and subjective interpretations of the feminization of aging. Secondly, I found it somewhat perplexing to approach the subject of older women in a holistic fashion when so many aspects of later life are diverse, full of cultural variance and individual idiosyncrasies. Finally, I have also to acknowledge, as an author from the second age, I could only research the area in a spirit of intergenerational solidarity. Although I tried my best to perform 'age suicide', I found this to be relatively problematic. It is extraordinarily enigmatic to empathize fully with older persons whose course of social mobility has come to an end, whose language is built upon life-long experience and invested with material belonging to other generations. Finally, one must not neglect the fact that education may not have all the answers for older women and must be supplemented by other institutions. However, this is not the same as saying that feminist educational gerontology has no critical role to play in the emancipation of older women, since it includes a theory of action where, through their sense of agency, learners are given the opportunity to act and change oppressive social structures. A feminist educational gerontology surely provides older women with the opportunity to form a type of organisation through which they can find strength and purpose in a common vision to denounce mystification and contribute to 
the enhancement of just and equitable relationships that further democracy, authenticity, and freedom.

\section{Biographical Notes}

Corresponding author: Marvin Formosa, European Centre of Gerontology, University of Malta, Msida MSD 06, Malta. Email: marvin.formosa@um.edu.mt.

Marvin Formosa is a lecturer within the European Centre of Gerontology, University of Malta whilst also holding visiting lectureship positions within the Department of Sociology of the same University and the International Institute on Ageing (United Nations-Malta). His principal fields of interest are in critical sociology of ageing, critical gerontology, educational gerontology, social class in later life, and Pierre Bourdieu's sociology.

\section{Acknowledgements}

I am indebted to Professor Peter Mayo, mentor and colleague, who responded to a draft version of this article. I am, of course, wholly responsible for the limitations and errors that remain.

\section{References}

Achenbaum, W. A. (1997). Critical gerontology. In A. Jamieson, S. Harper, and C. Victor, (Eds.) Critical approaches to ageing and later life (pp. 16-26). Buckingham: Open University Press.

Allman, P. (1984). Self-help learning and its relevance for learning and development in later life. In E. Midwinter, (Ed.) Mutual aid universities. Beckenham, Kent: Croom Helm.

Arber, S. and Ginn, J. (1991). Gender and Later life: a sociological approach of constraints. Beverly, CA: Sage.

Baars, J. (1991). Challenge of critical gerontology: the problem of social constitution. Journal of ageing studies, 5 (3): 219-243.

Battersby, D. (1987). From andragogy to gerogogy. Journal of educational gerontology, 2 (1): 4-10.

Battersby, D. and Glendenning, F. (1992). Reconstructing education for older adults: An elaboration of first principles. Australian Journal of Adult and Community Education, 32 (2): 115-21.

Bernard, J. (1976). The future of marriage. Harmonsdsworth: Penguin

Birren, J. E., Kenyon, G. M., Ruth, J-E., Schroots, J. J. F. and Svensson, T. (1996). (Eds.) Aging and biography. Explorations in adult development. New York: Springer.

Bourdieu, P. (1995). State nobility. Cambridge: Polity Press.

Browne, C.V. (1998). Women feminism and aging. New York: Springer.

Calasanti, T. (2004). Feminist gerontology and men. Journals of Gerontology Series B: Psychological Sciences and Social Sciences. 59B (6): S305-S314.

Cole, T. R., Kastenbaum, R., and Ray, R. E. (Eds.) (2000) Handbook of humanities and aging. New York: Springer.

Coleman, P. (1999). Creating a life story: the task of reconciliation. Gerontologist. 39 (2) 133-9. 
Coyle, J. M. (1997). (Ed.), Handbook of women and aging. Westport. Connecticut: Greenwood Press.

Delphy, C. and Leonard, D. (1992). Familial exploitation, Cambridge: Polity Press.

Ellsworth, E. (1989). Why doesn't this feel empowering? Working through the repressive myths of critical pedagogy. In L. Stone, (Ed.) The education feminism reader. New York, NY: Routledge.

Estes, C. L. (1979). The aging enterprise. San Francisco: Jossey Bass.

Estes, C. L. Biggs, S., and Phillipson, C. (2004). Social theory, social policy, and ageing: a critical introduction. Berkshire: Open University Press.

Findsin, B. (2004) Learning later. Malabar, FL: Krieger Publishing Company.

Formosa, M. (2000). Older adult education in a Maltese university of the third age: a critical perspective. Education and Ageing. 13 (3): 315-339

Formosa, M. (2002). Critical gerogogy: developing practical possibilities for critical educational gerontology. Education and Ageing. 17 (1): 73-85.

Foucault, M. (1980). Power/Knowledge. Brighton: Harvester Press.

Freire, P. (1972a). Pedagogy of the oppressed. Harmondsworth: Penguin.

Freire, P. 1972b). Cultural action for freedom. Harmondsworth: Penguin.

Freire, P. (1985). The politics of education: Culture, power and liberation. New York: Bergin and Garvey.

Garner, J. D. (1999). Feminism and feminist gerontology. In J. D. Garner, (Ed.) Fundamentals of feminist gerontology. Binghampton, NY: Haworth Press.

Gibson, D. and Allen, J. (1993). Parasitism and phallocentrism in social provisions for the aged. Policy Sciences, 26, 79-98.

Glendenning, F. (1991). What is the future of educational gerontology? Ageing and Society, 11 (2): 209-16.

Glendenning, F., and Battersby, D. (1990). Why we need educational gerontology and education for older adults: A statement of first principles. In F. Glendenning, and K. Percy (Eds.), Ageing, education and society: Readings in educational gerontology. University of Keele, Staffordshire: Association for Educational Gerontology.

Gramsci, A. (1971). Selections from the prison notebooks. In Q. Hoare and G. Nowell Smith (Eds.) London: Lawrence and Wishart.

Heath, S. (1987). Male feminism. In A. Jardine, and P. Smith, (Eds.), Men in feminism. New York: Routledge.

hooks, b. (1981). Ain't I a Women? Black Women and Feminism. Boston, MA: South End Press.

Hopkins, P. D. (1998). How feminism made a man out of me: The proper subject of feminism and the problem of men. In T. Digby, (Ed.), Men doing feminism. New York: Routledge.

Kimmel, M. S. (1995). (Ed.) The Politics of Manhood: Profeminist men respond to the mythopoetic men's movement (and the mythopoetic leader's answer). Philadelphia: Temple University Press.

Laslett, P. (1996). The intellectual dependence of the third age. In A. Schembri (Ed.) Education for the elderly: A right or an obligation. Malta: University of Malta.

Laws, G. (1995). Understanding ageism: Lessons from feminism and postmodernism', Gerontologist, 35 (1): 112-118.

Marx, K. (1963). Theses on Feuerbach. In T. B. Bottomore (Ed.) Karl Marx: Selected writings in sociology and social philosophy. Harmondsworth: Penguin.

Marx, K. (1964). The economic and philosophical writings of 1844. New York: International Publishers. 
Marx, K. and Engels, F. (1963). The German ideology. London: Lawrence and Wishart.

Mayo. P. (1999). Gramsci, Freire and adult education: possibilities for transformative action. London: Zed Books.

Midwinter, E. (1984). (Ed.) Mutual aid universities. Beckenham, Kent: Croom Helm.

Midwinter, E. (1987). The university of the third age as leisure provider. In J. Armstrong, E. Midwinter, and D. Wynne-Harley, (Eds.) Retired leisure: four ventures in post-work activity. London: Centre for policy on ageing.

Midwinter, E. (1996). Thriving people: the growth and prospects of the U3A in the UK. London: Third Age Trust.

Minkler, M. and Estes, C. (Eds.) (1999). Critical gerontology: perspectives from political and moral economy. Amityville, NY: Baywood.

Minkler, M. (1996). Critical perspectives in ageing: New challenges for gerontology. Ageing and Society, 16 (4), 467-87.

Moody, H. (1992). Gerontology and critical theory. The Gerontologist. 32 (3): 294-95.

Moody, H. (1993). Overview: What is critical gerontology and why is it important?, in T. Cole, W. Achenbaum, P. Jakobi and R. Kastenbaum, (Eds.) Voices and visions of ageing: toward a critical gerontology. New York: Springer.

Palmore, E. P. (1997). Sexism and ageism. In J. M., Coyle, (Ed.) Handbook of women and aging. Westport, Connecticut: Greenwood Press.

Phillipson, C. (1982). Capitalism and the construction of old age. London: Macmillan.

Ray, R. E. (1999). Researching to transgress: The need for critical feminism in gerontology. In J. D. Garner (Ed.), Fundamentals of feminist gerontology. Binghampton, NY: Haworth Press.

Sherwin, S., (1988). Philosophical methodology and feminist methodology. In L. Code, (Ed.) Feminist perspectives: Philosophical essays on methods and morals. Toronto: University of Toronto Press.

Sontag, S., (1975). The double standard of aging. In no longer young: the older women in America. Ann Arbor, MI: Institute of Gerontology.

Swindell, R., (1995). Intellectual changes in later life: why bother? Social Alternatives, 14 (2): $15-19$.

Swindell, R., 1997. U3As in Australia and New Zealand: their value to the wider community and new directions for future development. International journal of lifelong education, 16 (6): 474-90.

Vellas, P. 1997. Genesis and aims of the universities of the third age, European Network Bulletin, 1: 9-12.

Walker, A. (1981) Towards a political economy of old age, Ageing and Society. 1 (1): 73 94.

Weiler, K. (1991). Freire and a feminist pedagogy of difference. Harvard Educational Review, 61: 449-74.

Weiner, G., (1994). Feminism in Education: An Introduction. Buckingham: Open University.

Withnall A. and Percy, K. 1994. Good practice in the education and training of older adults, England: Ashgate.

Withnall, A., (2000). The debate continues: integrating educational gerontology and lifelong learning. In F. Glendenning (Ed.) Teaching and learning in later life, Aldershot: Ashgate. 